\title{
PERANCANGAN SISTEM INFORMASI PENGOLAHAN DATA TRANSAKSI PENERIMAAN DAN PENGELUARAN KAS UNTUK PERENCANAAN PENGENDALIAN KEUANGAN
}

\author{
Selvi Yona Sari ${ }^{1}$, Novi Trisna ${ }^{2}$ \\ Universitas Putra Indonesia "YPTK” Padang \\ selvi.yono@gmail.com, ${ }^{2}$ novi trisna@upiyptk.ac.id
}

\begin{abstract}
The aim of the research is to design and build an information system application for processing cash receipts and disbursements data for financial planning and control at the Wali Nagari Kenagarian Harau Office using the Java Netbean programming language and MySQL database which aims to speed up data entry for receipt and expenditure transactions cash and report presentation quickly, precisely and accurately. The conclusion in this study is the programming language Java Netbeans and MySQL proven to be able to be used in a performance that is fast, precise and accurate in data entry cash receipts and disbursements transactions, as well as more secure data security.
\end{abstract}

Keywords - Cash Receipts and Expenditures, Java Netbeans, MySQL

Abstrak - Tujuan penelitian adalah merancang dan membangun sebuah aplikasi sistem informasi pengolahan data transaksi penerimaan dan pengeluaran kas untuk perencanaan serta pengendalian keuangan pada Kantor Wali Nagari Kenagarian Harau dengan menggunakan bahasa pemrograman Java Netbean dan database MySQL yang memiliki tujuan untuk mempercepat entry data transaksi penerimaan dan pengeluaran kas dan penyajian laporan dengan cepat, tepat dan akurat. Kesimpulan dalam penelitian ini adalah bahasa pemograman Java Netbeans dan MySQL terbukti mampu digunakan dalam sebuah kinerja yang cepat, tepat dan akurat dalam entry data transaksi penerimaan dan pengeluaran kas, serta keamanan data lebih terjamin.

Kata Kunci - Penerimaan dan Pengeluaran Kas ,Java Netbeans, MySQL

\section{PENDAHULUAN}

Kemajuan ilmu pengetahuan dan teknologi sekarang ini sangatlah pesat dan sejalan pula dengan rumitnya dunia bisnis dan informasi. Salah satunya adalah dengan komputer. Komputer dapat menangani proses pengolahan data yang diolah menjadi suatu informasi yang sangat dibutuhkan, sehingga mampu menerobos keterbatasan manusia dalam hal kecepatan, ketelitian, serta dalam hal ingatan.

Khususnya dalam bidang pengolahan data transaksi penerimaan dan pengeluaran kas, pengambilan keputusan, penyusunan personalia, dan melaksanakan fungsi pengendalian keputusan. Disamping itu komputer dapat menyimpan data, memperbaiki data, serta mengambil informasi yang dibutuhkan. Dimana data atau informasi tersebut disimpan didalam media penyimpanan magnetik dan sejenisnya dalam bentuk file.

Hal ini dapat dijumpai pada Kantor Wali Nagari Harau yang telah menggunakan komputer dalam melakukan pengolahan data transaksi penerimaan dan pengeluaran kas dengan memanfaatkan pengolahan angka seperti Excel. Dimana hanya mengolah data yang bersifat sederhana, sehingga apabila ditinjau dari efisiensinya, penggunaan aplikasi tersebut akan terasa sekali kekurangannya, terutama dalam hal pembaharuan dan kontrol data. Namun dengan pesatnya perkembangan dan banyaknya jumlah data transaksi penerimaan dan pengeluaran kas yang diolah, maka paket pengolahan data angka tersebut tidak mampu menghasilkan informasi dengan cepat, efisien, dan akurat.
Oleh karena itu, penulis mencoba merancang sistem pengolahan data transaksi penerimaan dan pengeluaran kas sekaligus mengaplikasikannya ke dalam bahasapemrograman Java Netbeans dengan memberikan judul: "PERANCANGAN SISTEM INFORMASI PENGOLAHAN DATA TRANSAKSI PENERIMAAN DAN PENGELUARAN KAS UNTUK PERENCANAAN PENGENDALIAN KEUANGAN".

\section{LANDASAN TEORI}

Konsep Dasar Sistem Informasi

Berdasarkan defenisi mengenai sistem dan informasi yang telah dijelaskan di atas, maka dapat dikatakan bahwa sistem informasi merupakan gabungan dari empat bagian utama . Keempat bagian utama tersebut mencangkup perangkat lunak (software), perangkat keras (hardware), infrastruktur, dan sumber daya manusia (SDM) yang terlatih (I Putu Agus Eka Pratama, 2014: 10).

Komponen Sistem Informasi

Sistem informasi mengandung komponen-komponen seperti berikut (I Putu Agus Eka Pratama, 2014: 1114)

1. Input (masukan)

Sebuah informasi berasal dari data yang telah diolah dan diverifikasi sehingga akurat, bermanfaat, dan memiliki nilai. Komponen input ini berfungsi intuk menerima semua input (masukan) dari pengguna.

2. Output (keluaran)

Sebuah sistem informasi akan menghasilkan keluaran (output) berupa informasi. Komponen 
output berfungsi untuk menyajikan hasil akhir ke pengguna sistem informasi.

3. Software (Perangkat Lunak)

Komponen software (perangkat lunak) mencangkup semua perangkat lunak yang digunakan di dalam sistem informasi. Adanya komponen perangkat lunak ini akan membantu sistem informasi dalam menjalankan tugasnya dan untuk dapat dijalankan sebagaimana mestinya.

4. Hardware (Perangkat Keras)

Komponen hardware (perangkat keras) mencangkup semua perangkat keras komputer yang digunakan secara fisik didalam sistem informasi. Baik di komputer server maupun di komputer client.

5. Databse (Basis Data)

Komponen basis data berfungsi untuk menyimpan semua data dan informasi ke dalam suatu atau beberapa tabel. Setiap tabel memiliki field masing-masing. Setiap tabel memiliki fungsi penyimpanan masing-masing, serta antartabel dapat juga terjadi relasi.

6. Kontrol dan Prosedur

Kontrol dan prosedur adalah dua komponen yang menjadi satu. Komponen kontrol berfungsi untuk mencegah terjadinya berbagai gangguan dan ancaman terhadap data dan informasi yang ada didalam sistem informasi, termasuk juga sistem informasi itu sendiri beserta fisiknya (dalam hal ini komputer server).

7. Teknologi dan Jaringan Komputer Komponen terakhir didalam sistem informasi ini, yaitu teknologi dan jaringan komputer memegang peranan terpenting untuk sebuah

sistem informasi. Komponen teknologi mengatur software,hardware, database, kontrol dan prosedur, input, dan output, sehingga sistem dapat berjalan dan terkendali dengan baik.

Alat Bantu Desain Sistem

Pada perkembangan teknik pemrograman berorientasi objek, muncul sebuah standarisasi bahasa pemodelan untuk pembangunan perangkat lunak yang dibangun dengan menggunakan teknik pemrograman berorientasi objek. UML muncul karena adanya kebutuhan pemodelan visual untuk menspesifikasikan, menggambarkan, membangun, dan dokumentasi dari sistem perangkat lunak. UML merupakan bahasa visual untuk pemodelan dan komunikasi mengenai sebuah sistem dengan menggunakan diagram dan teksteks pendukung (Rosa dan Shalahuddin, 2015: 137). Penerimaan Kas

Kas merupakan salah satu akun atau rekening ynag disajikan oleh perusahaan sebagai salah satu elemen aktiva lancar. Kas merupakan terminal bagi arus lalu lintas transakisi dalam perusahaan. Semua transaksi atau tidak langsung pasti berhubungan langsung dengan kas.
Penerimaan kas perusahaan yang umum terjadi bersumber dari :

1. Penjualan barang dagangan atau jasa secara tunai

2. Penerimaan dari pelunasan piutang

3. Penjualan dari aktiva tetap

4. Penerimaan dari pinjaman

5. Penerimaan dari setoran modal pemilik

6. Hasil penjualan surat-surat berharga

7. Penerimaan kembali kelebihan uang muka dan biaya

8. Pendapatan lain-lain

Pengeluaran Kas

Pengeluaran kas yang lazim dilakukan oleh perusahaan dimaksudkan untuk memenuhi kebutuhan sebagai berikut :

1. Pembelian barang dagangan atau jasa secara tunai

2. Pelunasan utang

3. Pembelian dari aktiva tetap

4. Pembayaran biaya-biaya

5. Pembayaran prive

6. Pembayaran pajak

7. Penarikan Modal pemilik

8. Pemberian pinjaman oleh perusahaan

\section{METODOLOGI PENELITIAN}

Metodologi penelitian yang dilakukan pada penelitian ini meliputi :

1. Studi Literatur

Tahap ini dilakukan dengan cara mencari dan menggali informasi yang berhubungan dengan penelitian ini, baik dari buku, jurnal, internet dansumber lainnya yang mendukung penelitian ini.

2. Pengumpulan Data

Tahap ini dilakukan dengan cara mencatat data penerimaan kas dan pengeluarn kas.

3. Perancangan Sistem

Tahap ini dilakukan dengan mengunakan alat bantu rancangan sistem dengan menggunkan UML

4. Implemetasi Sistem

Tahap ini dilakukan dengan membuat sistem penerimaan dan pengeluaran kas dengan menggunakan bahasa pemograman java dan database mysql

5. Pengujian Sistem

Tahap ini dilakukan pengujian terhadap sistem yang telah dibangun untuk melihat keluaran dari setiap tahapan.

\section{ANALISIS DAN HASIL}

Dalam mengatasi setiap permasalahan sebelum menuju ke sasaran atau tujuan yang diinginkan, maka perlu dilakukan analisis terhadap permasalahan yang sebenarnya. Analisis sistem dapat didefenisikan sebagai penguraian dari suatu sistem yang utuh ke 
dalam bagian komponennya dengan maksud untuk mengindentifikasikan dan mengevaluasi permasalahan, hambatan yang terjadi dan kebutuhan yang diharapkan sehingga dapat diusulkan perbaikannya.

Analisis sistem dilakukan dengan tujuan untuk mengetahui kelemahan-kelemahan yang terjadi pada sistem yang sedang berjalan. Karena dengan dilakukannya analisis sistem yang sedang berjalan akan dapat memberikan kemudahan di dalam perancangan dan pembangunan terhadap sistem yang akan dibangun atau sistem baru. Dengan dilakukannya analisis terhadap sistem yang lama nantinya akan dapat dijadikan sebagai perbadingan, pengoreksian serta pengembangan dan perancangan kearah sistem yang baru.

Dengan merencanakan perancangan terhadap sistem yang baru diharapkan dapat meminimalisasi masalah yang terjadi pada sistem yang lama serta diharapkan berfungsi lebih baik dari sistem sebelumnya. Untuk itu perlu dianalisa secara ringkas tentang bagaimana prosedur dari aliran sistem informasi datanya.

\section{Analisis Sistem Lama}

Analisis terhadap sistem lama merupakan tahap awal dalam pengembangan sistem itu sendiri, hal ini dilakukan agar perbandingan antara sistem yang baru dengan yang lama dapat dilihat dengan jelas. Hal ini juga dapat dijadikan tolak ukur sejauh mana perkembangan sistem tersebut berhasil dilakukan. Oleh karena itu penulis akan menjabarkan bagaimana sistem yang saat ini sedang dilakukan di Kantor Wali Nagari Harau.

Berikut penulis akan menjelaskan bagaimana sistem lama yang sedang berjalan :

1. Bendahara mencatat data penerimaan dan pengeluaran kas secara manua atau masih menggunakan Excel untuk mengolah buku kas umum, buku bank nagari, dan buku kas pembantu pajak.

2. Setelah melakukan pencatatan penerimaan dan pengeluaran kas bendahara membuat laporan buku kas umum, laporan buku bank nagari, dan buku kas pembantu pajak serta laporan penerimaan dan pengeluaran kas bulanan pada akhir bulan dan laporan total penerimaan dan pengeluaran kas tahunan atau total kas keseluruhan untuk diberikan kepada sekretaris.

3. Kemudian sekretaris memeriksa semua laporan penerimaan dan pengeluaran kas yang telah diberikan sebelumnya oleh bendahara.

4. Setelah semua laporan penerimaan dan pengeluaran kas tersebut di periksa oleh sekretaris, selanjutnya diberikan kepada Wali Nagari.
Berikut ini gambar 3.1 memperlihatkan desain sistem lama yang sedang berjalan pada Kantor Wali Nagari Hara:

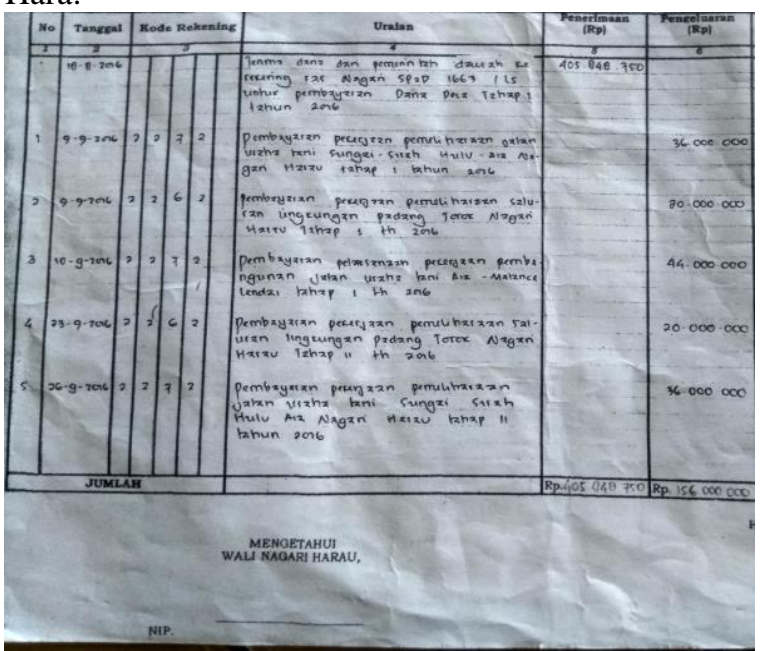

Desain Sistem LamaAnalisis Sistem Baru

Untuk mengatasi masalah yang dihadapi oleh sistem lama maka dibentuklah sistem baru, dimana proses penerimaan dan pengeluaran kas dapat dilakukan secara komputerisai sehingga memberikan kemudahan kepada bendahara dan dapat menghemat waktu dalam proses pengentrian data..

Desain Sistem Baru

Desain sistem baru merupakan suatu bentuk pengembangan terhadap sistem yang sedang berjalan, gunanya untuk mempercepat dan mengoptimalkan peralatan teknologi informasi dengan hasil dalam penghematan biaya dan waktu.

Prosedur perancangan sistem secara umum untuk pembangunan sistem dalam membangun asistem informasi pengolahan data transaksi penerimaan dan pengeluaran kas ini menggunakan perancangan sistem yang terdiri dari rancangan Use Case Diagaram, Class Diagram, Activity Diagram, dan Sekuence Diagram

\section{Use Case Diagram}

Use case menggambarkan bagaimana seseorang akan menggunakan atau memanfaatkan sistem, sedangkan aktor adalah seseorang atau sesuatu yang berinteraksi dengan sistem. Use case diagram menggambarkan bagaimana proses-proses yang dilakukan oleh aktor terhadap sebuah sistem.

Berikut gambar use case diagram : 


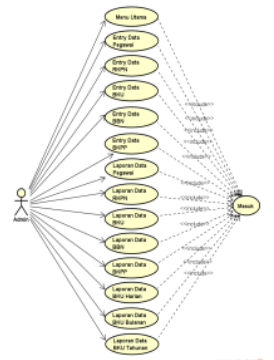

Gambar Use Case Diagram

Class Diagram

Class diagram memberikan gambaran hubungan antara tabel-tabel yang ada dalam database. Masingmasing class memiliki atribut dan metode atau fungsi sesuai dengan proses yang terjadi.

Berikut gambar class diagram:

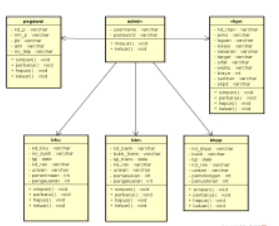

Gambar Class Diagram

Activity Diagram

Activity diagram merupakan sebuah diagram dimana dalam diagram tersebut terdapat semua aktivitas dalam sistem ini. Dalam activity diagram digambarkan aktivitas dari setiap aktor yang ada.

Activity Diagram Admin

Berikut gambar Activity Diagram Admin :

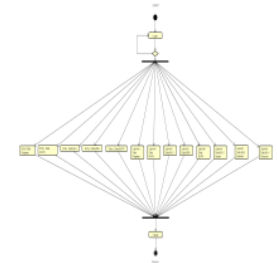

Gambar Activity Diagram

AdmiSequence Diagram

Sequence diagram menggambarkan kelakuan objek pada use case dengan mendeskripsikan waktu hidup objek dan message yang dikirimkan dan diterima antar objek.

Sequence Diagram Entry Data Buku Kas Umum Berikut gambar Sequence Diagram Entry Data Buku Kas Umum :

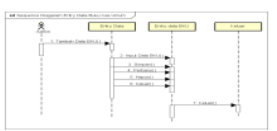

Gambar Sequence Diagram Entry Data Buku Kas Umum

Sequence Diagram Entry Data Buku Bank Nagari gambar Sequence Diagram Entry Data Buku Bank Nagari :

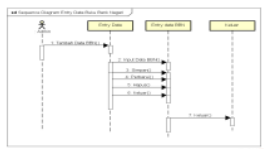

Gambar Sequence Diagram Entry Data Buku Bank Nagari 
Sequence Diagram Entry Data Buku Kas Pembantu Pajak

Berikut gambar Sequence Diagram Entry Data Buku Kas Pembantu Pajak :

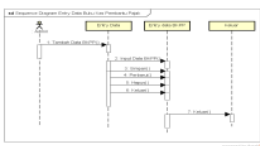

Gambar Sequence Diagram Entry Data Buku kas pembantu pajak

Sequence Diagram Laporan Data Buku Kas Umum Harian

gambar Sequence Diagram Laporan Data Buku Kas Umum Harian :

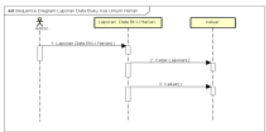

Gambar Sequence Diagram Laporan Data Buku Kas Umum Harian

Sequence Diagram Laporan Data Buku Kas Umum Bulanan

Berikut gambar Sequence Diagram Laporan Data Buku Kas Umum Bulanan :

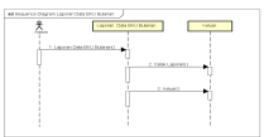

Gambar Sequence Diagram Laporan Data Buku Kas Umum Bulanan

Sequence Diagram Laporan Data Buku Kas Umum Tahunan

Berikut gambar Sequence Diagram Laporan Data Buku Kas Umum Tahunan :

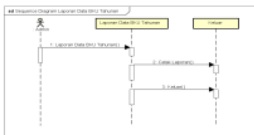

Gambar Sequence Diagram Laporan Data Buku Kas Umum Tahunan

Pengujian Sistem

Pengujian dan implementasi system bertujuan untuk melihat apakah sistem yang dirancang sudah sesuai dengan apa yang di inginkan atau belum, setelah dilakukannya pengujian dan implementasi, kualitas sebuah system akan terlihat tampilan program yaitu merupakan sub bab yang menjelaskan tentang proses dimulainya sampai program ini selesai dieksekusi, point-point pada sub bab ini akan menjelaskan tentang bagaimana sebuah form dijalankan dan apa saja fungsi yang terdapat pada form tersebut.

Halaman Entry Data Rencana Kerja Pembangunan Nagari

Halaman entry data Rencana Kerja Pembangunan Nagari merupakan halaman yang berfungsi untuk mengentrikan data Rencana Kerja Pembangunan Nagari ke dalam database. Untuk lebih jelasnya dapat dilihat pada gambar berikut :

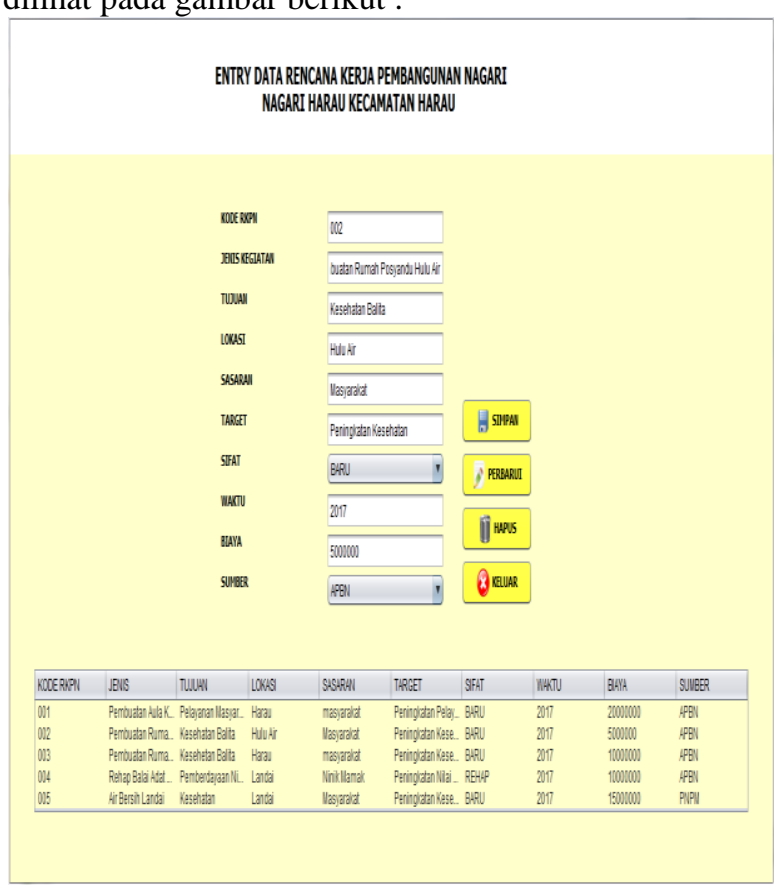

Gambar Halaman Entry Data Rencana Kerja Pembangunan Nagari 
Halaman Entry Data Buku Kas Umum

Halaman entry data Buku Kas Umum merupakan halaman yang berfungsi untuk mengentrikan data Buku Kas Umum ke dalam database. Untuk lebih jelasnya dapat dilihat pada gambar 4.13 berikut :

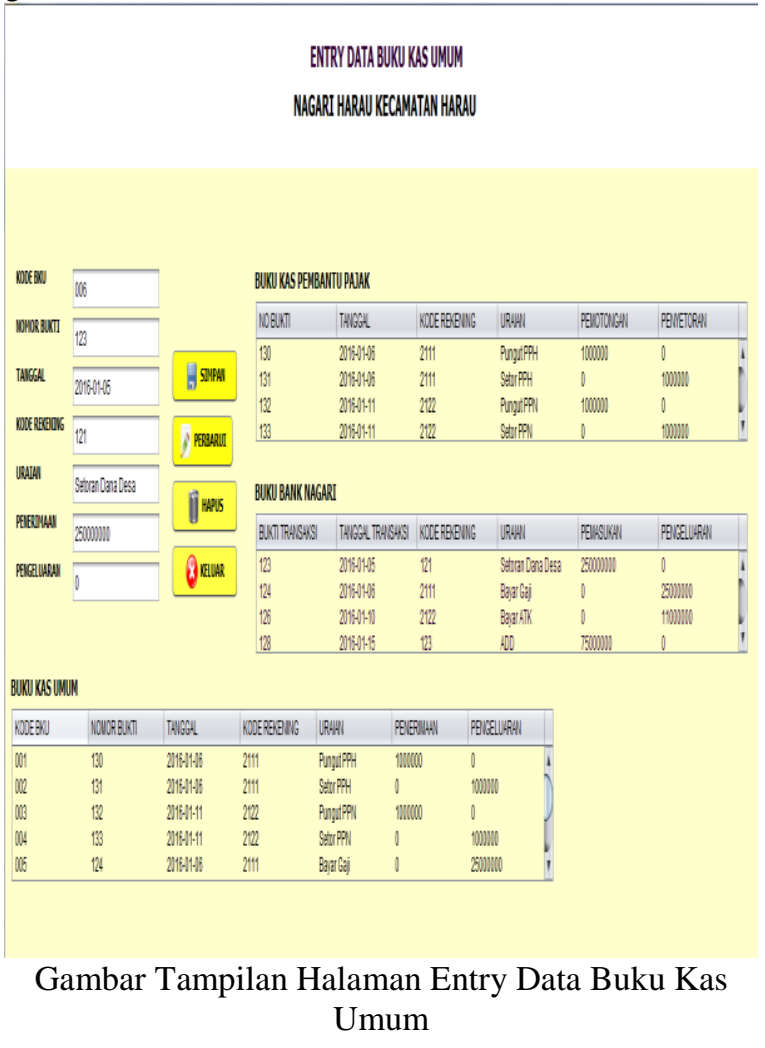

Halaman Entry Data Buku Bank Nagari

Halaman entry data Buku Bank Nagari merupakan halaman yang berfungsi untuk mengentrikan data Buku Bank Nagari ke dalam database. Untuk lebih jelasnya dapat dilihat pada gambar berikut :

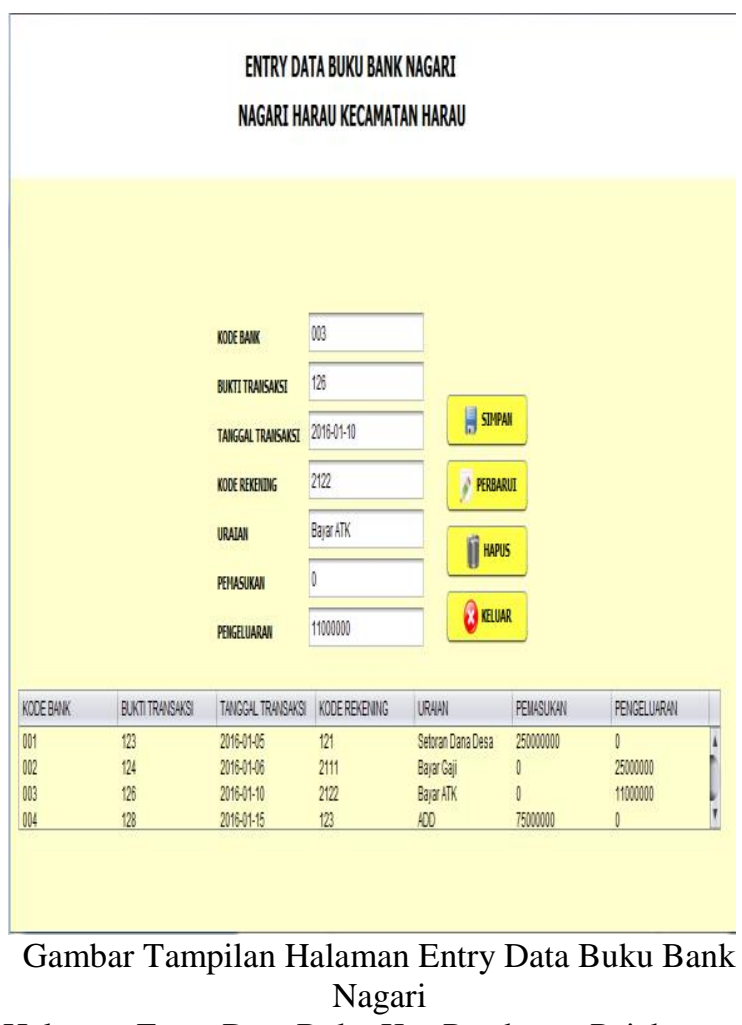

Halaman Entry Data Buku Kas Pembantu Pajak Halaman entry data Buku Kas Pembantu Pajak merupakan halaman yang berfungsi untuk mengentrikan data Buku Kas Pembantu Pajak ke dalam database. Untuk lebih jelasnya dapat dilihat pada gambar berikut :

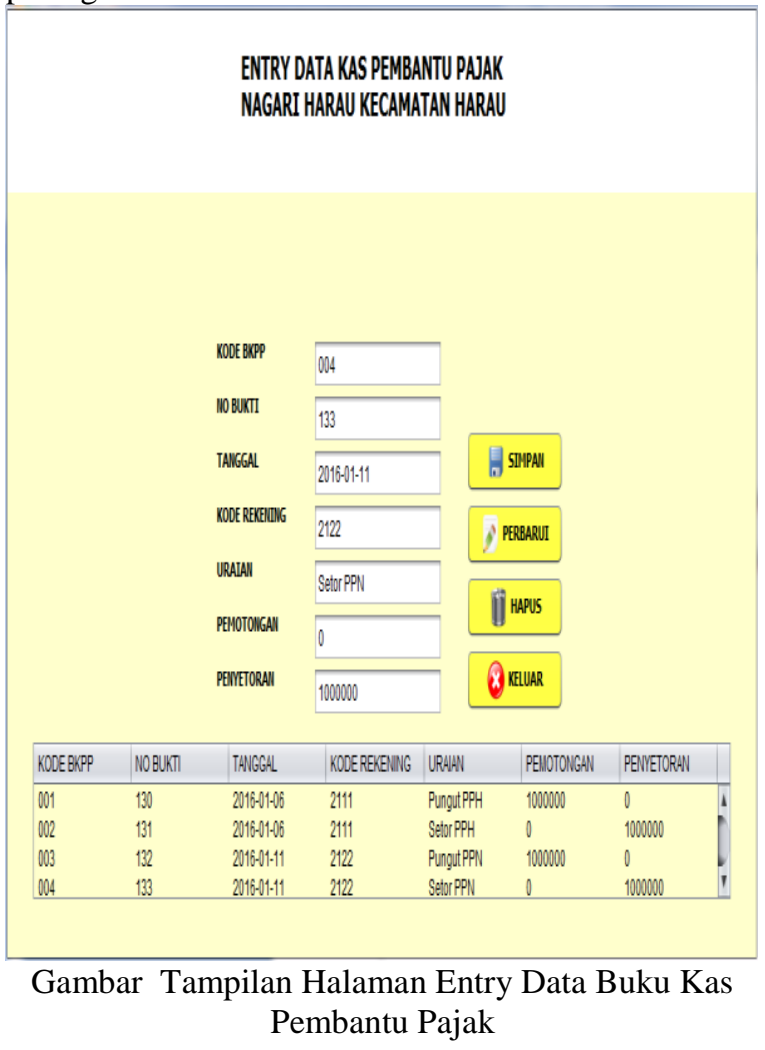


Halaman Laporan Data Rencana Kerja Pembangunan Nagari

Halaman laporan data Rencana Kerja Pembangunan Nagari merupakan halaman yang akan menampilkan laporan data Rencana Kerja Pembangunan Nagari.Untuk lebih jelasnya dapat dilihat pada gambar berikut :
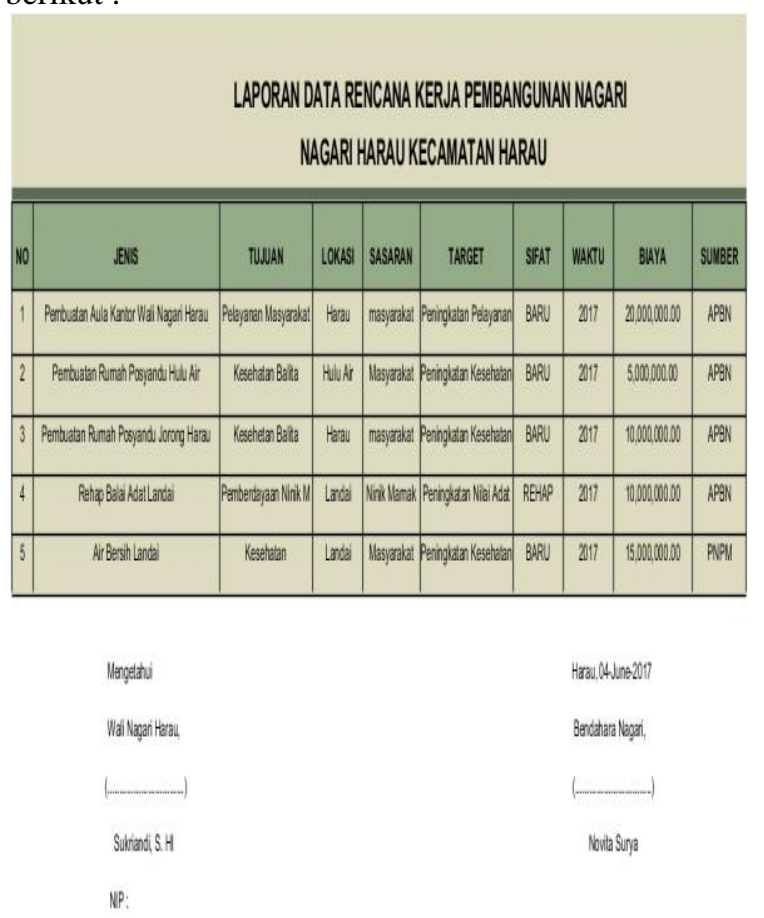

Gambar Tampilan Laporan Data Rencana Kerja Pembangunan Nagari

Halaman Laporan Data Buku Kas Umum

Halaman laporan data Buku Kas Umum merupakan halaman yang akan menampilkan laporan data Buku Kas Umum.Untuk lebih jelasnya dapat dilihat pada gambar berikut :

\begin{tabular}{|c|c|c|c|c|c|c|}
\hline \multicolumn{7}{|c|}{$\begin{array}{l}\text { LAPORAN DATA BUKU KAS UMUM } \\
\text { NAGARI HARAU KECAMATAN HARAU }\end{array}$} \\
\hline \multirow[t]{2}{*}{ KOOEBKU } & \multirow[t]{2}{*}{ OMOR BUKTII } & \multirow[t]{2}{*}{ 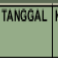 } & \multirow[t]{2}{*}{ KOOEREEENNG } & \multirow[t]{2}{*}{ URALN } & \multicolumn{2}{|c|}{ SALDO } \\
\hline & & & & & \begin{tabular}{|l|} 
PENERMMAaN \\
\end{tabular} & PENGELUARAN \\
\hline 001 & 130 & 16616 & 2111 & PungupPH & $1,000,000.00$ & 0.00 \\
\hline 002 & 131 & 16616 & 2111 & Sebr PPH & 0.00 & $1,000,000.00$ \\
\hline 003 & 132 & $11 / 1 / 1 / 16$ & 212 & PunguPPN & $1,000,000,00$ & 0.00 \\
\hline 004 & 133 & $111 / 1 / 16$ & 2122 & Setx PPN & 0.00 & $1,000,000,00$ \\
\hline 005 & 124 & 16616 & 2111 & Baya Cal & 0.00 & $25,000,000.00$ \\
\hline 006 & 123 & 15516 & 121 & Setran Dena Desa & $250,000,000.00$ & 0.00 \\
\hline 007 & 126 & $1 / 101 / 16$ & 2122 & Baya ATK & 0.00 & $11,000,000.00$ \\
\hline$\infty 08$ & 128 & $1 / 1 / 5116$ & 123 & $A 00$ & $75,000,000,00$ & 0.00 \\
\hline$\infty x^{\infty}$ & 134 & 81816 & 272 & Terma Dara Dar penentinan Dererah & $405,848,750.00$ & 0.00 \\
\hline 010 & 135 & 9916 & 272 & Pembageran Peterazan daban & 0.00 & $36,000,000,00$ \\
\hline 011 & 136 & 16616 & 273 & Peremerman Denara & $30,000,000,00$ & 0.00 \\
\hline \multirow{2}{*}{\multicolumn{5}{|c|}{ JUMLAH }} & $762,848,750.00$ & $74,000,000.00$ \\
\hline & & & & & \multicolumn{2}{|c|}{$688,848,750.00$} \\
\hline \multicolumn{5}{|c|}{ Mengeteriu } & \multicolumn{2}{|c|}{ Harau,04.June-2017 } \\
\hline \multicolumn{5}{|c|}{ Wal Negan Hara, } & \multicolumn{2}{|c|}{ Benchanar Negage, } \\
\hline \multicolumn{5}{|c|}{$(\ldots$} & \multicolumn{2}{|c|}{$(\ldots \ldots$} \\
\hline \multicolumn{5}{|c|}{ Sulvand, S.HI } & \multicolumn{2}{|c|}{ Novila Sung } \\
\hline
\end{tabular}

Gambar Tampilan Laporan Data Buku Kas Umum

Halaman Laporan Data Buku Bank Nagari

Halaman laporan data Buku Bank Nagari merupakan halaman yang akan menampilkan laporan data Buku Bank Nagari.Untuk lebih jelasnya dapat dilihat pada gambar berikut :

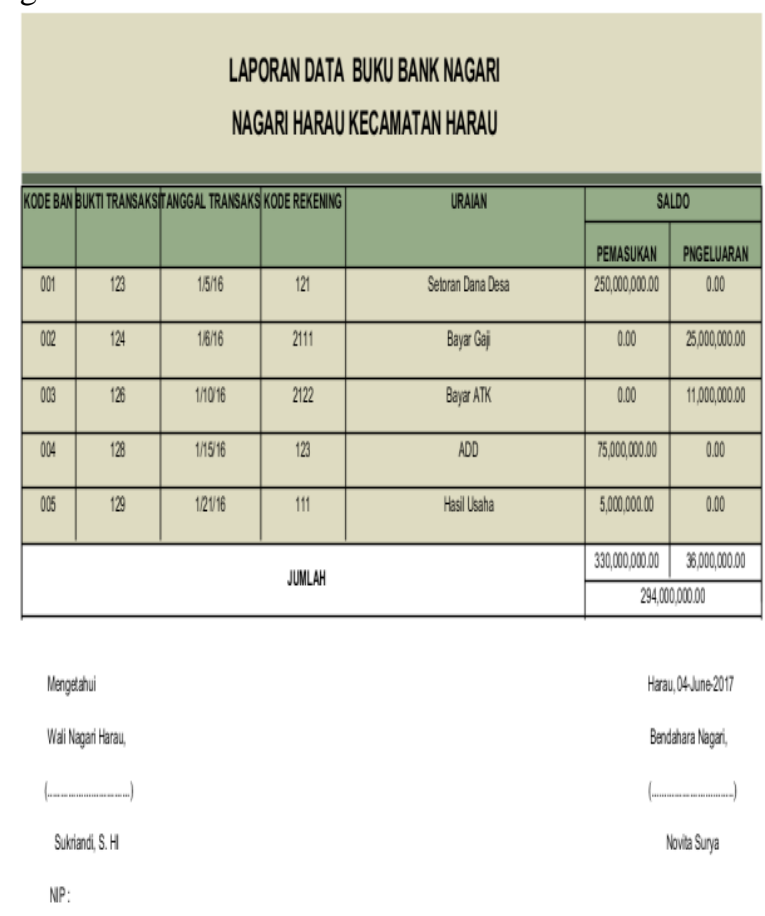

Gambar Tampilan Laporan Data Buku Bank Nagari 
Halaman Laporan Data Buku Kas Pembantu Pajak Halaman laporan data Buku Kas Pembantu Pajak merupakan halaman yang akan menampilkan laporan data Buku Kas Pembantu Pajak.Untuk lebih jelasnya dapat dilihat pada gambar berikut :

\begin{tabular}{|c|c|c|c|c|c|c|}
\hline \multicolumn{7}{|c|}{$\begin{array}{c}\text { LAPORAN DATA BUKU KASPENBANTUPAJAK } \\
\text { NAGARI HARAUKECAMATAN HARAU }\end{array}$} \\
\hline KODEBKPP & BUKत & TAIGGAL & KODEREEENIIG & URAAW & PEIOTONGAN & PENEEORAN \\
\hline OOI & 130 & 16116 & 2111 & PungutPPH & 1,000000000 & 0000 \\
\hline Oe. & 131 & 1616 & 2111 & SAOP PPA & 000 & 1,00000000 \\
\hline$\infty$ & 132 & 11111116 & 2122 & PungutPPN & $1,000,00000$ & 000 \\
\hline 0.4 & 130 & 1111116 & 2122 & Sata PFN & 000 & 1,0000000 \\
\hline \multirow{2}{*}{\multicolumn{5}{|c|}{ JUMLAH }} & 2000,00000 & $2,000,00000$ \\
\hline & & & & & \multicolumn{2}{|c|}{000} \\
\hline
\end{tabular}

\begin{tabular}{|c|c|}
\hline Ileygetalui & Hrau,O4June2017 \\
\hline 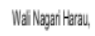 & Bendideral logat, \\
\hline 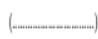 & 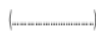 \\
\hline Sikizaris S.H & Novita Sing \\
\hline
\end{tabular}

Gambar Tampilan Laporan Data Buku Kas Pembantu Pajak

Halaman Laporan Data Buku Kas Umum Harian Halaman laporan data Buku Kas Umum harian merupakan halaman yang akan menampilkan laporan data Buku Kas Umum harian.Untuk lebih jelasnya dapat dilihat pada gambar berikut :

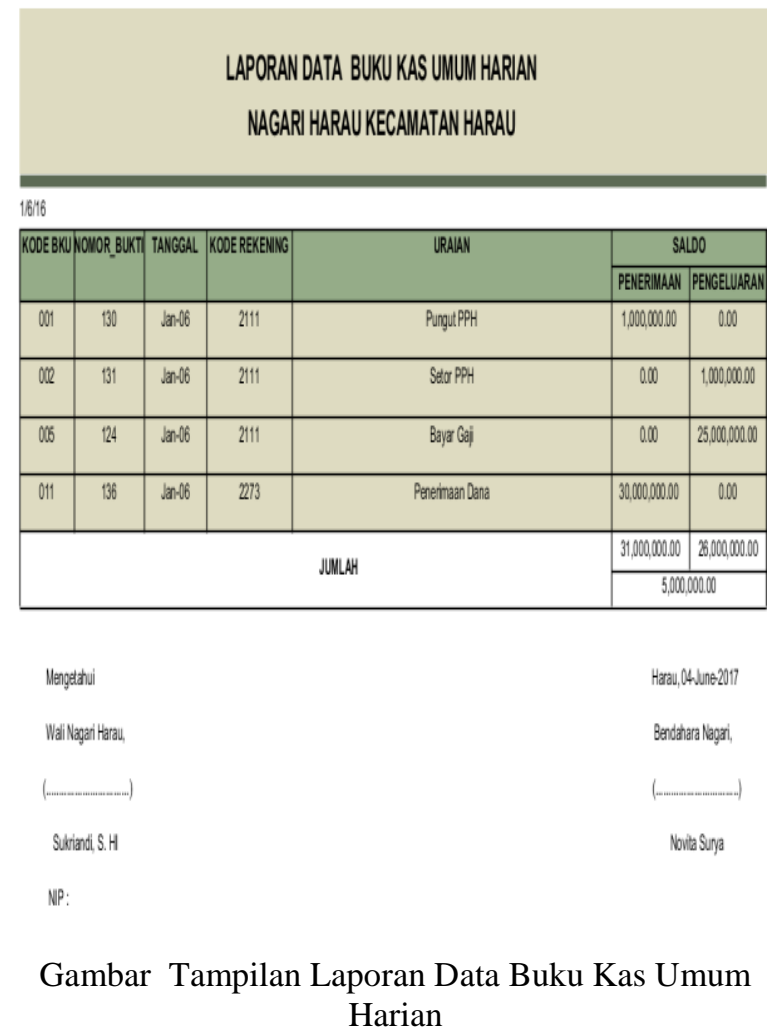

Halaman Laporan Data Buku Kas Umum Bulanan Halaman laporan data Buku Kas Umum bulanan merupakan halaman yang akan menampilkan laporan data Buku Kas Umum bulanan.Untuk lebih jelasnya dapat dilihat pada gambar berikut :

\begin{tabular}{|c|c|c|c|c|c|c|}
\hline \multicolumn{7}{|c|}{$\begin{array}{l}\text { LAPORAN DATA BUKU KAS UMUM BULANAN } \\
\text { NAGARIHARAU KECAMATAN HARAU }\end{array}$} \\
\hline \\
\hline \multicolumn{2}{|c|}{ KOOE BKU NOMOR BUKT } & \multirow[t]{2}{*}{ BULAN } & \multirow[t]{2}{*}{ KODE REKENNG } & \multirow[t]{2}{*}{ URALAN } & \multicolumn{2}{|c|}{ SALDO } \\
\hline & & & & & PENERIIIAAN & $\begin{array}{l}\text { PENGELUARAN } \\
\end{array}$ \\
\hline$\infty 1$ & 130 & January & 2111 & Pungu PPH & $1,000,000000$ & 0.00 \\
\hline$\omega 2$ & 131 & Januay & 2111 & Seta PPH & 0.00 & $1,000,000,00$ \\
\hline 003 & 132 & Januay & 2122 & Pungu PPN & $1,000,00000$ & 0.00 \\
\hline mas & 133 & January & 2122 & Seta PPN & 0.00 & $1,000,000000$ \\
\hline 005 & 124 & January & 2111 & Bgar Cal & 0.00 & $25,000,000.000$ \\
\hline 06 & 123 & Januay & 121 & Seloran Dana Desa & $250,000,000000$ & 0.00 \\
\hline$\infty 07$ & 126 & Januay & 2122 & Byya ATK & 0.00 & $11,000,000.00$ \\
\hline$\infty 6$ & 128 & Januay & 123 & $A D O$ & $75,000,000.00$ & 0.00 \\
\hline 011 & 136 & Januey & 273 & Peneremanan Dana & $30,000,000.00$ & 0.00 \\
\hline \multirow{2}{*}{\multicolumn{5}{|c|}{ JUMAH }} & $35,000,000.00$ & $38,000,000.00$ \\
\hline & & & & & \multicolumn{2}{|c|}{$319,000,000,00$} \\
\hline \multicolumn{5}{|c|}{ Mergeterui } & \multicolumn{2}{|c|}{ 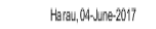 } \\
\hline \multicolumn{5}{|c|}{ Wal Negani Harau, } & \multicolumn{2}{|c|}{ Bendahara Negant, } \\
\hline \multicolumn{5}{|c|}{(} & \multicolumn{2}{|c|}{ 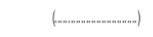 } \\
\hline \multicolumn{5}{|c|}{ Sulvernd, S.HI } & \multicolumn{2}{|c|}{ Novita Sung } \\
\hline
\end{tabular}

Gambar Tampilan Laporan Data Buku Kas Umum Bulanan 
Halaman Laporan Data Buku Kas Umum Tahunan Halaman laporan data Buku Kas Umum tahunan merupakan halaman yang akan menampilkan laporan data Buku Kas Umum tahunan.Untuk lebih jelasnya dapat dilihat pada gambar berikut :

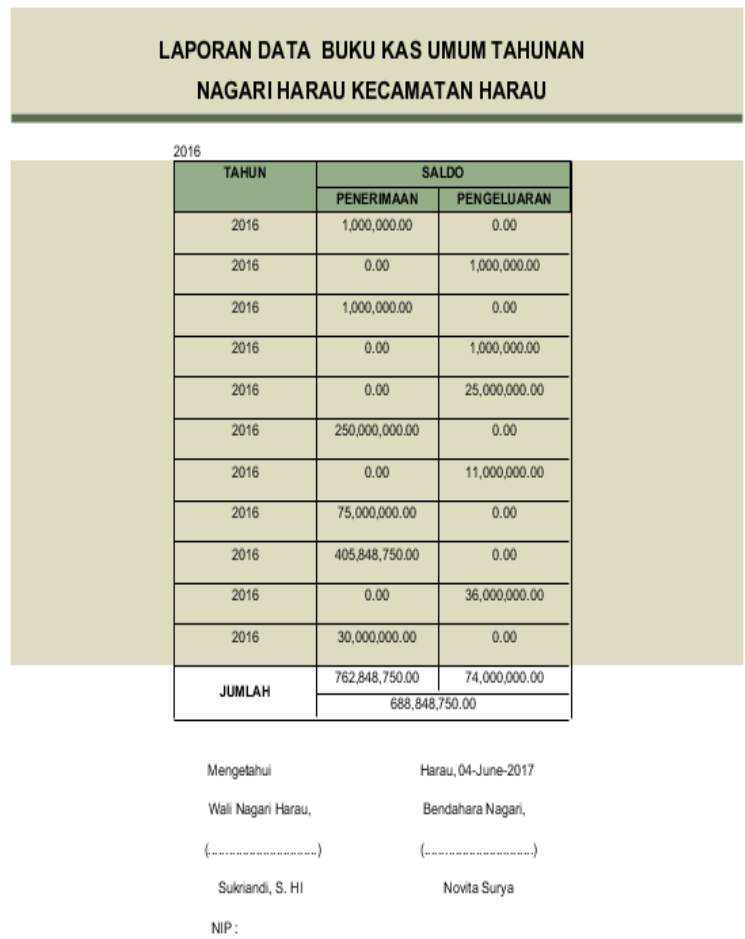

Gambar Tampilan Laporan Data Buku Kas Umum Tahunan

Kesimpulan

\section{KESIMPULAN DAN SARAN}

Berdasarkan dari penelitian yang telah penulis lakukan pada Kantor Wali Kenagarian Harau maka dapat diambil kesimpulan sebagai berikut :

1. Dengan adanya sistem baru dapat membantu dalam pengolahan data transaksi penerimaan dan pengeluaran kas pada Kantor Wali Nagari Harau, serta dapat mengurangi kesalahan pada saat pemrosesan data.

2. Dengan adanya penerapan aplikasi pengolahan data transaksi penerimaan dan pengeluaran kas ini, maka dapat membantu dalam penyajian laporan dengan cepat, tepat, dan akurat.

3. Sistem informasi pada aplikasi ini dapat mengatasi masalah yang timbul pada Kantor Wali Nagari Harau, seperti mempercepat kinerja, keamanan dan keakuraratan data lebih terjamin.

Saran-Saran

Agar penerapan sistem yang baru ini dapat berjalan dengan baik maka berikut disampaikan beberapa saran-saran dalam penggunaan sistem yang baru ini :
1. Perlu meyakinkan pegawai Kantor Wali Nagari Harau yang terlibat dalam pemakaian sistem ini, bahwa kehadiran komputerisasi hanyalah sebagai alat bantu dalam pengolahan data untuk memudahkan pekerjaan yang dihadapi.

2. Sebelum sistem baru ini diterapkan , diharapkan diadakan pelatihan-pelatihan terhadap staf yang berkompeten dengan sistem untuk meningkatkan sumber daya manusia dan mempermudah penggunaaan sistem.

3. Dalam penerapan sistem komputerisasi pada sistem yang baru sebaiknya didukung oleh perangkat yang memadai baik dari segi manusia maupun dari segi peralatannya.

4. Perlunya dilakukan pendekatan, pemeliharaan dan pengembangan sistem di masa akan datang untuk menjaga kelangsungan hidup sistem tersebut.

\section{DAFTAR PUSTAKA}

[1] Sugiyanto, Sukadi ,Bambang Eka Purnama. 2013. Sistem Informasi Penjualan Pada Butik Luwes Fashion Kecamatan Tulakan. 5 halaman.

[2] Setyowati, Dwi, Yudha Indra Permana. 2013. Sistem Pakar Diagnosa Penyakit Tanaman Padi Berbasis Web. Volume 6 nomor 1, 9 halaman.

[3] Sophian, Sophan. 2014. Pengimplementasian Dan Perancangan Sistem Informasi Penjualan Dan Pengendalian Stok Barang Pada Toko Swastika Servis (SS) Bangunan Dengan Menggunakan Bahasa Pemrograman Visual Basic 6.0 Didukung Dengan Database MySQL. Volume 16 nomor 2, 11 halaman.

[4] Sovia, Rini dan Jimmy Febio. Maret 2011. Membangun Aplikasi E-library Menggunakan HTML, PHP SCRIPT, dan MySQL Database. Vol. 3 nomor 1 , 16 halaman.

[5] Pratama, I Putu Agus Eka. 2014. Sistem Informasi dan Implementasinya. Bandung : Informatika.

[6] S.A, Rosa dan M. Shalahuddin. 2014. Rekayasa Perangkat Lunak Terstruktur dan Berorientasi Objek. Bandung : Informatika.

[7] Sutabri, Tata. 2012. Aanalisis Sistem Informasi. Yogyakarta : Andi Offset.

[8] Sutabri, Tata. 2012. Konsep Sistem Informasi. Yogyakarta : Andi.

[9] Kadir, Abdul. 2014. Pengenalan Sistem Informasi Edisi Revisi. Yogyakarta: Andi.

[10] Hidayatullah, Priyanto. 2015. Visual Basic .Net. Bandung : Informatika Bandung 